\title{
Česká vláda vstupuje na eurofinanční trh s novou strategií zadlužování
}

\author{
František Vencovsky $\hat{y}^{1}$
}

Úvahy české vlády o únosném růstu státního dluhu a o možnostech jeho financování se dostávají do nové polohy. Nastoluje se otázka dostupnosti vnitřních zdrojů, jejich hranice i ceny, a tedy otázka výhodnějšího nebo vủbec přijatelného čerpání zahraničních zdrojů. Do takové situace se ostatně dostává dříve nebo později fiskální politika každého státu, když je narušena rovnováha jeho finančního hospodaření. Je proto zcela přirozené, že vzájemné propojování národních úvěrových vztahů je nejen projevem a jedním z východisek při řešení rostoucích potíží vládních rozpočtů a různých přístupů $\mathrm{k}$ jejich zvládnutí, ale i jedním z vážných projevi̊ procesu světové a v naší situaci prioritně evropské ekonomické globalizace. Mezinárodní a ve většině případů nadnárodní kapitál získává nový a stále širší prostor pro své využití i ve finančních potížích různých národních ekonomik, a dokonce jak ukazuje vývoj v Evropské unii - i u zemí ekonomicky silných a dříve významně věřitelských.

K takovému obratu dochází i v př́istupech české vlády k řešení finančního problému, který se běžně, i když stále dost eufemisticky nebo přiliš účetnicky označuje jako dluhová služba. Svým rozsahem a svými souvislostmi jde však o více než o krátkodobé komerční kalkulace nebo počty. Vláda se rozhodla k emisi dluhopisů v eurech, a tedy k financování svých potřeb kapitálem, který hledá své využití na eurotrhu. Vstupuje na stranu poptávky na tomto trhu, a to zatím částkou jedné miliardy eur - při stávajícím kurzu zhruba 32 až 33 mld. Kč.

Celkové zahraniční zadlužení České republiky koncem roku 2003 dosáhlo 894 mld. Kč, tj. $33 \%$ hrubého domácího produktu, zatímco v Polsku už $43 \%$ a v Mad’arskudokonce $59 \%$. Tyto rozdíly jsou převážně pozůstatkem odlišného přístupu socialistických vlád k zadlužování v tzv. volných měnách v době před rokem 1990, kdy pro Státní banku československou a pro Ministerstvo financí byla zvlášt charakteristickým rysem snaha detailně regulovat devisové hospodářství, opatrně přistupovat $\mathrm{k}$ jeho uvolňování a zejména $\mathrm{k}$ čerpání zahraničních úvěrů. Částka doposud přijatých zahraničních úvěrů je ve struktuře státního zadlužení, které koncem minulého roku dosáhlo 493 mld. Kč, tedy 20,5\% hrubého domácího produktu, celkem nepatrná a představuje pouze 2,7 \% hrubého domácího produktu, a to hlavně z úvěrů, které poskytla Evropská investiční banka. Česká republika zatím nemá na mezinárodním finančním trhu dluhopisủ žádné závazky.

Proto je rozhodnutí o čerpání vládních úvěrů v zahraniční na eurotrhu zásadním obratem v dosavadní strategii financování rozpočtových deficitů. Vytvářejí se nové a velmi citlivé souvislosti mezi rovnováhou vládních financí, únosností výdajů státního rozpočtu a devizovou pozicí země. Dluhová služba, zejména její úroková složka se stává stále vážnějším prob-

1 Prof. JUDr. František Vencovský, Katedra měnové teorie a politiky Fakulty financí a účetnictví Vysoké školy ekonomické v Praze. 
lémem při rozhodování o struktuře výdajů státního rozpočtu. Úroky ze státního dluhu se stále zvyšují - v roce 2001 to bylo 20,5 mld. Kč, v roce 2004 se očekává 25,6 mld. Kč.

Poučné je i srovnání s obdobnou situací, do jaké se dostávají ostatní země, které v květnu 2004 vstoupily do Evropské unie. Emise polských a mad’arskýchdluhopisů se setkávaly s př́znivým ohlasem $\mathrm{v}$ souvislosti s procesem restrukturalizace, zejména modernizace výroby. Avšak nové emise Polska a Mad'arskauž takový ohlas nemají, protože jsou určeny především $\mathrm{k}$ tomu, aby kryly rozpočtové deficity. Jsou to prostě rizikové dluhopisy a s takovým ohlasem musí počítat i emise českých vládních dluhopisů.

\section{Propojování fiskálních a monetárních zájmů}

Důvody k rozhodnutí o čerpání zahraničního úvěru emisí vládních dluhopisů jsou různé a mohou se diametrálně rozcházet. Nabízí se především prostá kalkulace, zda pro takovou emisi jsou příznivější podmínky na domácím nebo na zahraničním finančním trhu, např́klad porovnáním provizí, jaké se platí bankám, které si vezmou na starost všechny aktivity spojené s organizováním emise dluhopisů. Vážnější a zpravidla rozhodující jsou odhady a kalkulace přejímacího kurzu emitovaných dluhopisů, v podstatě odhad výnosů, jaké budou mít pro své majitele později podle vývoje na finančním trhu.

Pro situaci na českém kapitálovém trhu nelze předpokládat, pokud emisi vládních dluhopisů neorganizuje Česká národní banka, že by došlo při dojednávání obchodních podmínek emise dluhopisů k významnějším rozdílům mezi českými a evropskými tržními podmínkami. Investoři, zejména banky jsou už tak propojeny, že si svou vzájemnou konkurencí vyrovnávají přístupy $\mathrm{k}$ určení provizí za provádění emise vládních dluhopisů. $\mathrm{K}$ vážnějším rozdílům však může dojít a zřejmě bude docházet $v$ odhadech investorů, kteří budou kupovat české dluhopisy, o jejich výnosnosti, tedy v odhadech efektivního úrokového př́inosu z držby českých dluhopisů podle vývoje na českém a evropském finančním trhu.

Úrokový výnos z vládních dluhopisů, které se dosud emitovaly na českém trhu, je v pohledu na stav a vývoj úrokových relací stále přitažlivý, a to i se zřetelem k malému riziku, resp. k jistotě věřitelské pozice investora.

\begin{tabular}{|c|c|c|c|c|}
\hline \multicolumn{5}{|c|}{ Státní dluhopisy na českém trhu } \\
\hline emise & \multicolumn{2}{c|}{ na trhu v dubnu 2004 } \\
\hline označení & splatnost roků & nominální úrok - \% & úrokový výnos - \% & referenční cena \\
\hline 707 & 5 & 6,75 & 2,0 & 103,6 \\
\hline 772 & 6 & 5,70 & 3,0 & 106,8 \\
\hline 731 & 10 & 6,40 & 3,9 & 112,5 \\
\hline 822 & 18 & 4,60 & 5,1 & 95,0 \\
\hline
\end{tabular}

Při čerpání úvěru v eurech se setkávají kritéria fiskální a monetární politiky nejen v pohledu na kurzové souvislosti čerpaného úvěru, ale i v pohledu na souvislosti s peněžní emisí a s dopady na finanční trh. Na devizovém př́ijmu ze získaných europrostředků má z hlediska vývoje platební bilance, zejména její struktury prioritní zájem Česká národní banka. Pokud by se staly součástí její devizové zásoby a byly zablokovány jako rezerva pro financování vážnějších výkyvů v devizové pozici státu, byla by výsledkem takového postupu emise českých peněz, které by dostala vláda za získané a centrální bance předaná eura. Př̀i takovém postupu by však vláda jako dlužník nezískala nic z čerpaného euroúvěru, protože 
tento úvěr mohl být nahrazen př́mým emisním úvěrem v korunách, i když s rizikem inflačních účinků.

Reálnější a v naší měnové situaci smysluplnější bude postup, při kterém devizové prostředky z euroúvěru budou - což bývá pravidlem - předány České národní bance do její devizové zásoby s protipoložkou pohledávky za státním rozpočtem a pak postupně uvolňovány vládě na financování potřeb, pro které byla vlastně přijata zahraniční půjčka. Byl by to postup bez inflačního rizika, pokud ovšem proti emitovaným penězům budou stát reálné hodnoty. Pak bude záležet na tom, co se za tyto devizové prostř̌edky pořídí, protože právě to bude vyjádřením pravého smyslu tohoto způsobu vládního zadlužování.

\section{Střetávání produktivity a spotř̌eby}

Pro rozhodnutí o emisi českých eurodluhopisů a pro kalkulace o jejich pozici na evropském trhu byly mnohem závažnější důvody než propočty vývoje tržních podmínek. Neodbytně a už zvlášt naléhavě se nastoluje otázka, zda k financování stále rostoucího státního dluhu a při stále tíživější dluhové službě je k dispozici dostatečná tvorba českého kapitálu, zda jsou v české ekonomice k dispozici dostatečné kapitálové zdroje. Vývoj v průběhu transformačního procesu i v posledních letech není př́iznivý.

Chybí kapitál, který by se nabízel k střednědobému nebo k dlouhodobému využití. $\mathrm{V}$ české ekonomické situaci nejsou zatím vytvořeny podmínky pro zájem na tvorbě úspor, které by byly dostatečným zdrojem pro financování výrobních investic. Právě naopak - převládá tendence $\mathrm{k}$ růstu spotř̌eby. Průměrný čistý výnos (po zdanění) z termínovaných vkladů se pohybuje kolem $1 \%$ a není motivací $\mathrm{k}$ vyšší spořivosti. Ve struktuře vkladů převažuje u domácností i u podniků dlouhodobá tendence růstu netermínovaných vkladů při současném poklesu termínovaných vkladů, i když u domácností je tento nežádoucí vývoj zmírňován růstem vkladů u stavebních spořitelen. U domácností - i vlivem téměř agresivních reklam - převládá snaha udržet si nebo dokonce zvýšit životní standard nad úroveň dosahovaných př́ijmů, a to i bankovními výpůjčkami. Spotřebitelské úvěry na nákup zboží, splátkové úvěry atp. v rozsahu 10 až 70 tisíc korun poskytují banky při úročení kolem $23 \%$ p. a. Zadlužení domácností se během roku 2003 zvýšilo o $31 \%$ a dosahuje 244 mld. Kč. Trvale se i při tomto riziku zvyšuje tempo spotřeby domácností - z meziročního zvýšení v průměru roku 2002 o 3,9 \% až na 7,3 \% v průběhu roku 2003.

V situaci kapitálové chudoby však dochází k pozoruhodnému paradoxu, když čeští investoři - banky, firmy, domácnosti atd. - ukládají stále více své úspory do cizích cenných papírů, zejména dluhopisů. České investice do zahraničních dluhopisů se zvýšily z 22 mld. Kč v roce 1998 na 250 mld. Kč v roce 2003. Je to nejen důsledkem toho, že český trh nemá co nabídnout, ale i projevem důvěry k cizím cenným papírům. $\mathrm{V}$ porovnání s tím, kolik depozit získávají české banky od firem a domácností, vyplývá, že se zvyšuje jejich odliv do zahraničí.

Je zřejmé, že zájem investorů o použití volného kapitálu k financování vládních potřeb není př́liš intenzivní a zůstává stále otevřenou otázkou, zda a za jakých podmínek by banky byly ochotny financovat vládu, i kdyby jejich kapitálové vybavení bylo dostatečné. Není to tak jednoznačné. Stále tíživější dluhová služba - k tomu riziko velkého objemu úvěrů garantovaných vládou - je faktorem, který nesporně ovlivňuje rozhodování investorů, zejména bank, když hledají výnosnější a spolehlivější alokací kapitálu.

Do rozhodování vlády o čerpání zahraničního úvěru tedy vstupují kritéria a motivy, které jsou mnohem závažnější než běžné komerční kalkulace, než prosté „kupecké počty“. 
Jde o národohospodářské, celospolečenské úvahy. Moderní demokratický stát ve svých základních zájmech a funkcích sleduje stav a situaci celé společnosti - nejen její úroveň ekonomickou a sociální, ale také úroveň jejího vzdělání, kultury, zdraví, bezpečnosti atd. Do státní nebo spíše vládní politiky vstupují určité prvky národní nebo vůbec společenské solidarity, tedy politiky, která má jednak zájem na liberálním fungování svého ekonomického základu, a tedy na své maximální ekonomické výkonnosti, jednak také zájem na harmonickém vývoji celé společnosti, na prosazování prvků určitého společenského zájmu, a to v takové míře, aby tyto prvky nejen nenarušily její liberální základ, ale naopak umožnily jeho bezporuchové fungování. Jde o sladění politiky směřující k maximální tvorbě zdrojů na straně jedné a k zajištění národních a společenských zájmů na straně druhé, tedy o rozhodování, co je v tomto solidaristickém pohledu nezbytné, prioritní a také „co si vláda může dovolit a na co má“.

Tato národohospodářská kritéria vstupují zvlášt naléhavě do úvah vlády o čerpání zahraniční úvěrové výpomoci, nebot jde v naší situaci skutečně o výpomoc. Záleží proto na jednoznačném určení účelu, jaký se sleduje tímto úvěrovým postupem. Konkrétně bude vyjádřen a specifikován tím, co se za získaná eura pořídí, k čemu se použijí. Jakékoliv jiné zdůvodnění tohoto účelu by bylo zamlžením smyslu zahraniční úvěrové politiky.

Bez závad, z hlediska fiskální a monetární politiky „čistý“ a podle všech kritérií ekonomické efektivnosti přijatelný by byl pouze úvěr na investice nebo na aktivity, které zvyšují produktivitu. K takovému „,bezproblémovému“ využití euroúvěru by mohlo dojít, pokud by byl směrován na určité konkrétní akce, u kterých výnos převyšuje úhradu dluhové služby, která vznikla přijetím úvěru. Takové použití zahraničního úvěru zvyšuje stav vládního majetku obdobně jako u každého výnosově kalkulujícího dlužníka a navíc vytváří devizové zdroje na své zaplacení.

Tato kritéria jsou samozřejmostí při rozhodování zahraničních investorů o jejich aktivitách v České republice. Stav př́mých zahraničních investicí na konci roku 2003 dosáhl už 1 219 mld. Kč a FDI se staly rozhodujícím faktorem v procesu restrukturalizace a modernizace výrobní základny a ekonomického růstu, ale pouze za předpokladu, že dosažené zisky budou reinvestovány opět v české ekonomice. Tento př́ístup má ovšem své hranice. Zahraniční investoři při rozhodování o alokaci svých financí kalkulují z hlediska vlastních dlouhodobých zájmů, tedy kdy se bude končit s reinvesticí zisků do české ekonomiky a kdy se přejde k jejich repatriaci. Dividendy, které si zahraniční vlastníci podnikající v České republice převedli „domů“, dosáhly v roce 2002 částky 32,7 mld. Kč a v roce 2003 už částky 43,3 mld. Kč. Mění se tím struktura finančního účtu platební bilance a devizová pozice státu.

S přihlédnutím $\mathrm{k}$ této tendenci ve vývoji přímých zahraničních investic by mělo být zájmem vládní politiky nahradit jejich příliv - pokud nestačí a zřejmě ještě dlouho nebude stačit tvorba domácího kapitálu - také využitím čerpaného euroúvěru, a to právě aplikací kritérií, kterými se řídí zahraniční investoři.

Ve vládní investiční politice však zpravidla nejde o úzce vymezené konkrétní akce, ale často o široce koncipované záměry ve výdajích státního rozpočtu, při kterých se dá - často v zamlžených „makropohledech“ a někdy i v modelových konstrukcích matematicky přesně propočítaných - jen hrubě usuzovat na vztah takových investic k ekonomické výkonnosti země. Lze jasněji a moderně formulovat tyto cíle jako zvýšení mezinárodní konkurenceschopnosti země, pokud jí rozumíme „schopnost země vytvářet srovnatelně více bohatství než jiné země“ (podle „World Competitiveness Yearbook“).

Vládní investice do modernizace dopravy, do zlepšování životního prostředí, do vzdělání atp. mají nesporně vztah k zvyšování výkonnosti české ekonomiky, k růstu společenské 
produktivity práce, ale ztrácí se při nich jasný konkrétní a snadno propočitatelný ekonomický efekt, aby byl spolehlivým vodítkem pro využití čerpaného devizového úvěru. Do rozhodování o těchto široce koncipovaných investičních záměrech se prosazují dílčí regionální a oborové zájmy a navíc se začínají prolínat i s financováním spotřeby, např́íklad u investic do bydlení. Bylo by to oslabením produktivitních kritérií vládní investiční politiky právě při rozhodování o použití zdrojů z euroúvěru a také vážným oslabením devizové pozice České republiky.

\section{Zahraniční úvěr a rozpočtové deficity}

Vážným rizikem pro dlouhodobou rovnováhu vládních financí by proto byl postup, při kterém by úvěru, který je čerpán v eurech, bylo využito $\mathrm{k}$ financování vládní spotřeby. Jejím základním rysem je - ostatně jako u každého úvěru, kterým se financují provozní výdaje - zhoršení majetkového stavu vládního, resp. státního hospodářství, tedy vytváření dluhu bez reálné majetkové, zejména investiční protipoložky. Takový úvěr slouží k udržení dosavadního spotřebního standardu ve vládním hospodaření za cenu zdlužování a bylo by jím i použití vypůjčených eur na krytí deficitů státního rozpočtu. Znamenal by i ohrožení devizové rovnováhy, když ani není zřejmé, z jakých zdrojů - z úspor ve vládním hospodaření nebo ze zdrojů ve vyšším daňovém zatížení - by byl takový spotřební úvěr splácen.

Fiskální politika směřující ke snížení deficitů a později k vyrovnanému státnímu rozpočtu se stává výraznou prioritou i ve spojení se záměrem vyrovnat se s kritérii Evropské unie při rozhodování o přijetí eura jako nové měny, a tedy o vstupu do eurozóny, jak se s tímto krokem uvažuje pro roky 2008 až 2010. Deficity veřejných financí se staly kritickým a nejvíce rizikovým článkem právě $v$ této dlouhodobě koncipované monetární politice. I když veřejný dluh svým podílem $38 \%$ na hrubém domácím produktu je ještě dost vzdálen od př́ípustných $60 \%$ podle maastrichtských kritérií vstupu do eurozóny, rozdíl mezi vývojem veřejných financí v České republice a v zemích Evropské unie se nebezpečně zvyšuje, protože struktura veřejných financí a jejich deficitů je kvalitativně jiná než v zemích Evropské unie. Hlavní př́ičinou jsou deficity, které vznikly jednak s financováním transformačního procesu, když státní rozpočet na sebe přejímá dluhy privatizovaných bank a podniků, jednak s financováním státního důchodového účtu, když se mění poměr mezi produkující a důchodovou generací. Nelze ani přehlédnout zatížení výdajové strany státního rozpočtu př́liš blahovolnou nebo štědrou sociální politikou.

Ke krytí vládní spotřeby, resp. k profinancování rozpočtových deficitů se využívaly i devizové př́ijmy z privatizace vládního majetku. Šlo nejen o postup, při kterém se kapitál rozpouští do spotřeby, ale také o postup, který má své hranice v možnostech privatizace. Vláda realizuje nebo připravuje prodej Unipetrolu, Telecomu a hnědouhelných dolů, tedy pokračování privatizační politiky. V roce 2004 však - po zkušenostech z minulých let a v souvislosti s reformou veřejných financí a pod tlakem prioritní politiky hospodářského růstu a snižování nezaměstnanosti - stojí vláda před rozhodováním, jakou strategii volit pro využití privatizačních př́ijmů, „aby to bylo pro stát nejvýhodnější“ (předseda vlády v Hospodářských novinách 23.4.2004). Do úvah o takové strategii tedy zcela nově vstupuje otázka úvěru čerpaného na eurotrhu. Rozhodně by to tedy neměl být úvěr do spotřeby, tím méně do vládní spotřeby, když právě pro vládní politiku se stává prioritou hospodářský růst a obstarání finančních zdrojů pro jeho zabezpečení.

Čerpání a později i splácení euroúvěru úzce souvisís vývojem kurzu koruny na devizovém trhu a na vzájemném vztahu mezi změnou kurzu koruny na straně jedné a mírou státního zadlužení na straně druhé. Podaří-li se zvyšovat během trvání úvěru kurz koruny 
a bude-li tedy při splatnosti úvěru euro levnější než v současné době, tedy než 32-33 Kč, bylo by to ulehčením pro státní rozpočet, protože na takovém vývoji by vláda jako dlužník získala.

Tomuto fiskálnímu zájmu by odpovídal i zájem měnové politiky v př́rštích letech, kdy se česká měna připravuje na vstup do eurozóny. Při stávajícím kurzu eura je česká ekonomika pro ostatní země Evropské unie př́iliš laciná. Ceny hrubého domácího produktu vytvořeného v České republice představují $43 \%$ cen téhož produktu vytvořeného v Evropské unii - propočítané porovnáním vnitřních cen a podle průměrného nominálního kurzu; ceny průměrného spotřebního koše představují 50 \% v cenách Evropské unie. České produkty na trhu zboží, služeb a kapitálu jsou tedy pro eurozónu laciné, kupní síla eura je v České republice mnohem vyšší než v jeho vlasti. Jde o disproporci, která je z hlediska zájmu na rovnovážné pozici české výroby na evropském konkurenčním trhu dlouhodobě neúnosná. Stávající rozdíly v cenových hladinách a nízký kurz koruny jsou zatím vážnou bariérou na cestě k dosažení rovnocenné pozice v eurozóně. Naproti tomu bude třeba počítat také s tím, že svou poptávkou po eurech v době splatnosti úvěru bude vláda působit i když přechodně - na zvýšení jeho kurzu.

Dalším vážným problémem při rozhodování o čerpání zahraničního úvěru v eurech je - vedle rozhodování o jeho použití - odhad situace na kapitálovém trhu v příštích letech. Nelze přehlížet riziko dostupnosti eura v době splatnosti úvěru, zda - i při málo reálném předpokladu stejného kurzu eura jako v době čerpání úvěru - bude na finančním trhu dostatek českého kapitálu na nákup eura. Vládní finanční politika svými úvěrovými postupy silně ovlivňuje situaci na finančním trhu s dopady na vývoj úroku. a tedy i na soukromé podnikání, kterému se zdražuje úvěr. To ovšem tlačí na produktivitu celého národního hospodářství a s těmito důsledky při splácení euroúvěru je třeba počítat. Nelze vyloučit, že může tedy dojít k určitému rozchodu fiskální a měnové politiky právě v úrokové politice. Česká národní banka snižuje svou základní úrokovou sazbu z tzv. repoúvěrů, která ovlivňuje vývoj úroků na finančním trhu.

\begin{tabular}{|l|c|c|c|}
\hline \multicolumn{3}{|c|}{ Úrokové sazby } \\
\hline & \multicolumn{3}{|c|}{ roční průměr } \\
\hline & $\mathbf{2 0 0 1}$ & $\mathbf{2 0 0 2}$ & $\mathbf{2 0 0 3}$ \\
\hline základní repo ČNB & 6,0 & 4,5 & 2,3 \\
\hline mezibankovní trh PRIBOR 3měsíční & 5,2 & 3,6 & 2,0 \\
\hline bankovní úvěry nově čerpané & 6,3 & 4,0 & 3,7 \\
\hline celkový stav úvěrů & 7,0 & 6,2 & 5,2 \\
\hline celkový stav vkladů & 3,0 & 2,2 & 1,4 \\
\hline
\end{tabular}

Pro strukturu českého kapitálového trhu je příznačné, že

- i při snižování úrokové úrovně není poptávka podniků po bankovních úvěrech do výroby; převažuje financování ze zahraničí formou přímých zahraničních investic;

- v české úvěrové poptávce převažuje zájem vládních financí; úrokový výnos z emitovaných vládních dluhopisů je sice nižší než u komerčních úvěrů, ale bankám tato situace dost vyhovuje, protože jde o úrokové výnosy bez rizika;

- v úrokové struktuře dochází jednak k výrazné diferenciaci mezi druhy bankovních úvěrů, jednak k rostoucímu rozdílu, spreadu mezi úroky z depozit a úroky z úvěrů; tento vývoj souvisí s poklesem zájmu domácností na tvorbě úspor při růstu zájmu 
na vy̌šsí spotř̌ebě; úroky na spotřebu se pohybují kolem $23 \%$, úroky z hypotečních úvěrů kolem $4,2 \%$ atd.; spread mezi průměrem úroků z nových bankovních úvěrů a průměrem úroků z termínovaných depozit dosahuje čtyři procentní body.

Nedostatečná tvorba střednědobého a dlouhodobého kapitálu, která je na finančních trzích i výsledkem malého zájmu domácností o vyšší spořivost, se proto zvlášťcitlivě projeví ve vývoji poptávky po kapitálových zdrojích při splácení euroúvěru. Vládní finanční situace svým propojením s finančním trhem negativně v té době ovlivní podnikové výrobní kalkulace.

Tyto kurzové a úrokové účinky emise českých vládních dluhopisů v eurech, zejména jak se budou projevovat při jejich nákupech na finančních trzích, se dají do určité míry ztlumit nebo v některých př́padech i eliminovat swapovými dohodami mezi Ministerstvem financí jako emitentem a investory jako kupujícími. Jejich smyslem bude přenést kurzová a úroková rizika na protistranu a zajistit si tak aspoň kurzovou a úrokovou stabilitu. Jak dalece se podaří těmito dohodami upevnit pozici české strany, bude záležet na finanční a zejména devizové síle partnerů kapitálového trhu. Nebude to pro českou nabídku dluhopisů pozice snadná, protože mezi subjekty na straně poptávky patří silné investiční společnosti. V každém případě budou swapové dohody pouze okrajovou záležitostí s krátkodobými účinky. Jde totiž o standardní „komerční počty“, protože kalkulace o krytí vládních potřeb ze zahraničních zdrojů a o jejich únosnosti pro vládní finance jsou předurčeny zásadními úvahami o cílech vládní finanční politiky a o strategii jejich naplňování.

Rozhodování o použití finančních prostředků z emise vládních dluhopisů na devizovém trhu se dostává do náročnějších, ekonomicky i politicky citlivějších úvah než při dosavadních emisích na vnitřním trhu. Vyhrocují se obě extrémní orientace smyslu státního zadlužování v př́ístích letech - zda prioritně do aktivit, o kterých je jasné, že zvyšují ekonomickou výkonnost a že si minimálně vytvoří zdroje pro své zaplacení, nebo zda na úhradu výdajů, které se zvyšují, aby se jimi udržel dosavadní trend vládní spotřeby, a to jak v jejím rozsahu, tak v její struktuře. Rozhodování mezi oběma extrémními variantami úzce souvisî s kritérii, která doposud pro naši společnost po roce 1989 nebyla nastavena: jde jednak o pozici české ekonomiky v nových podmínkách evropského partnerství, jednak o zásadní ujasnění reformy nebo spíše restrukturalizace veřejných financí. 